\title{
Structural Adjustment, Industrialisation, and Export Promotion
}

\author{
SHAHRUKH RAFI KHAN and SHAHEEN RAFI KHAN
}

\begin{abstract}
The main objective of this paper was to explore if trade liberalisation has ushered in the large scale de-industrialisation that is feared by some to follow in its wake and whether it has been successful in enhancing export promotion. We relied on several different kinds of evidence to demonstrate that de-industrialisation has not coincided with the intensive structural adjustment period while export growth has. However, both industrialisation and export promotion in Pakistan have been below potential, below the mean for low income countries and have not even kept pace with progress in this regard in the low income country group. We were not able to establish, possibly due to the paucity of time-series observations, that either industry or exports generated positive externalities for or used resources more productively than the rest of the economy.
\end{abstract}

\section{INTRODUCTION}

One of the nationalistic fears of structural adjustment induced trade liberalisation is that it may lead to de-industrialisation and one of the expected gains of such structural adjustment is export promotion. ${ }^{1}$ Considerable trade liberalisation took place over the period under study. This is evident from the much smaller premia on imported goods and from the sharp reduction in the effective rates of protection. ${ }^{2}$ The objective of this paper is to test if de-industrialisation has occurred in Pakistan and whether Pakistan has been able to successfully promote exports since the onset of structural adjustment. ${ }^{3}$

Shahrukh Rafi Khan is Senior Fellow, Sustainable Development Policy Institute, Islamabad. Shaheen Rafi Khan is Economics Consultant at Sustainable Development Policy Institute, Islamabad.

Authors' Note: Thanks are due to Javed Akbar Ansari, Tariq Banuri, and Mohsin S. Khan for comments. Thanks are also due to Sajid Kazmi for extensive and able research assistance.

${ }^{1}$ Industry comprises value-added in mining, manufacturing, construction, electricity, water and gas. Since manufacturing constitutes the largest component of industry and is viewed as having special significance, and hence it is also used as a separate category for the analysis.

${ }^{2}$ For evidence that trade liberalisation in Pakistan has been significant, see Aftab (1994) and Kemal (1997).

${ }^{3}$ Neither industrialisation nor export promotion should be viewed as ends in and of themselves. Thus the links of industrialisation and export promotion to economic growth also need to be empirically investigated. For evidence on the impact of industrialisation on economic growth, see Kaldor (1967); Weiss (1988); Khan and Bilginsoy (1994) and Khan, Bilginsoy and Alam (1997). For the impact of export promotion on growth see Tyler (1981); Feder (1982); Kavoussi (1984); Balassa (1985); Chow (1987) and Dollar (1992). Scholars who have questioned these findings include Jung and Marshall (1985); Dodaro (1991); Sheehey (1992); Levine and Renelt (1992) and Khan and Bilginsoy (1994). 
A nationalistic perspective is that structural adjustment induced tariff cutting would result in a flood of cheap and high quality imports which are the products of advanced technology and which would result in de-industrialisation. Also, structural reforms induced sudden and sharp increase in the costs of production, because of higher utility and borrowing costs, could have at least a short term adverse impact on industrial growth. The original concern with de-industrialisation occurred in the context of the "Dutch Disease," whereby prosperity strengthened the currency, made imports cheaper and resulted in a decline in local industrialisation. To an extent, structural adjustment can have a similar effect since it can stabilise the currency and make imports more attractive. Remittances could have a similar effect by strengthening the currency.

The theory of infant industry protection suggests that developing countries need time to build themselves up to face competition. However, the fear is now expressed that conditionality driven trade reforms will make them indefinitely dependent on primary products with declining terms of trade. ${ }^{4}$ An alternative empirically based perspective is that developing countries have spoiled industrialists who have refused to become competitive and are hence a drain on the rest of the economy. Thus no further protection is warranted and it is high time that this sheltered industrial sector confront competition via trade liberalisation. Competitiveness would also be induced by expecting this sector to break into export markets and economic benefit would result from the higher profitability and from the earning of much needed foreign exchange.

In Section 2, we estimate the contribution of domestic demand, import substitution and export-promotion to industrial growth. In Section 3 we review the change in industrialisation and export orientation over time and also review Pakistan's industrialisation and export orientation relative to cross-country experience. We end with a summary of findings.

\section{DETERMINANTS OF INDUSTRIALISATION}

The method utilised to decompose industrial growth is taken from Lewis (1969, pp. 17-22). This can be summarised in the following equation:

$$
\Delta X=\mu_{1}(\Delta \mathrm{D})+\mu_{1}(\Delta \mathrm{X})+\left(\mu_{2}-\mu_{1}\right) \mathrm{Z}_{2} \quad \ldots \quad \ldots \quad \ldots
$$

Where,

$X=$ Domestic production.

$D=$ Domestic final demand.

$X=$ Exports.

$Z_{2}=$ Total supply in terminal year.

${ }^{4}$ For a brief review of the terms of trade controversy see Singer (1989). 
$\mu_{1}=$ Domestic production to total supply in base year.

$\mu_{2}=$ Domestic production to total supply in the terminal year.

Equation (1) represents the decomposition of total industrial production resulting from a change in domestic demand, exports and import substitution. The detailed derivation is presented in Appendix I. ${ }^{5}$ The results of this exercise are presented below in Table 2 for three periods based on political and economic regimes correspond roughly with the populist Bhutto government (1971-1977), the military regime of Zia-ul-Haque (1978-1988) and the democratic governments that followed. The last period 1987-88-1990-91 represents the intensive bout of structural adjustment. $^{6}$ The sample of industrial goods we selected to compute Table 2 accounts for 85 percent of the total value of industrial production.

The story that emerges from the numbers in Table 1 above is plausible and consistent with policy changes that have historically been taking place. In the consumer goods industry, import-substitution was already declining (negative) as a source of industrial growth in the base period (1970-81) i.e., imports increased their share of the domestic market. Exports accounted for 10 percent of industrial growth in the base period and this increased to 14 percent in the 1980-88 period. This trend continued in the structural adjustment period (1987-91) where export promotion was a very important part of industrial growth (48 percent) and import displacement accounted for 11 percent of industrial growth. ${ }^{7}$ Thus Pakistan appears to have managed to deal with trade liberalisation in the consumer goods industry rather well, over the time period under study, by displacing imports and promoting exports.

The intermediate goods industry is where the fears of de-industrialisation at first appear more well founded. In the base 1970-81 period, import substitution accounted for 29 percent of industrial growth. This declined to 10 percent in the 1980-88 period and a negative 49 percent in the structural adjustment period. Thus it appears that imports penetrated the domestic market following liberalisation. On closer examination of the disaggregated findings, it is evident that much of the change has occurred due to the petroleum product group for which import substitution contributed 38 percent as a source of industrial growth in 1970-81 but -17 percent in 1987-91. This is not an industry for which Pakistan is resource rich. Market penetration is also evident for the pesticides, insecticides, fungicides and

${ }^{5}$ Thanks to Tariq Banuri for suggesting the derivation.

${ }^{6}$ The structural adjustment period is still under way in 1997, although the new government of Nawaz Sharif has altered the macro focus from demand restraint to supply incentives. The latest Census of Manufacturing Industries available was for 1990-91.

${ }^{7} \mathrm{~A}$ positive number for import substitution could represent both more production due to protection or import displacement via greater efficiency and competitiveness. By looking at long term trends, it becomes possible to identify which force is operative. 
Table 1

Sources of Industrial Growth (Percentages)

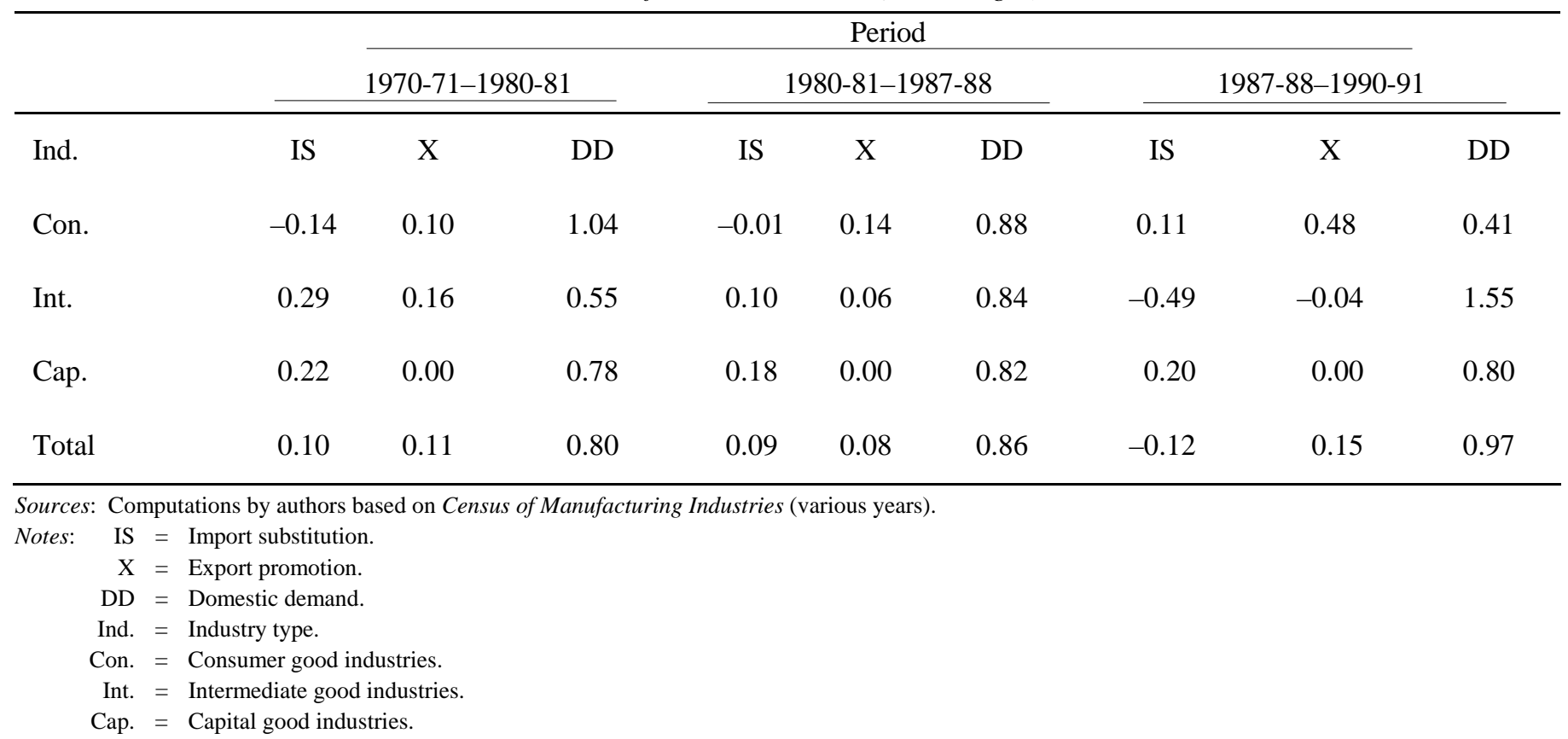

All numbers are weighted averages and the rows for all industry categories for all periods add to 1 . We were unable to exactly match the items in the electric machinery and equipment and non-electric machinery categories of the capital good industries for the 1987-88/1990-91 period to the earlier periods. Thus there is not complete comparability in the last and earlier two period estimates for capital goods. 
herbicide group and the compressed liquified and solidified gas group, although these product groups made no contribution to industrial growth in the base year. Thus while liberalisation is associated with de-industrialisation for the intermediate good category, the disaggregated data show the high negative number $(-0.49)$ overstates the case. ${ }^{8}$

Export promotion in the intermediate goods sector consistently declined with exports accounting for 16 percent of industrial growth in the first period, 6 percent in the second period and -4 percent in the third period (i.e. $\Delta X$ was negative). The negative exports could have resulted both from Pakistan's losing export markets to fierce international competition, after having got a leg up earlier, and also from domestic demand absorbing intermediate goods that might otherwise have been exported.

There has been little change in the capital goods sector. Import substitution accounted for roughly a fifth of industrial growth through out the period and exports, as one might expect, accounted for nothing so domestic demand explained the rest of industrial growth. In aggregate terms, there has been negative import substitution or import penetration over the period because of the intermediate goods industry. Export promotion declined somewhat in the second period (due to intermediate goods) and then picked up in the third period (due to consumer goods). This mirrors findings we demonstrate in the next section.

\section{INDUSTRIALISATION AND EXPORT ORIENTATION IN PAKISTAN IN A CROSS-COUNTRY CONTEXT}

This last section contained an analysis of change in the determinants of industrialisation. However, so far, there has been no mention of the magnitude and change in industrialisation itself, both in absolute terms and relative to cross-country experience. We now turn to these issues.

In Table 2 below, we present the broad changes that have taken place in Pakistan with respect to industrialisation and export orientation. Industrialisation and export orientation are measured in terms of the ratio of the value-added in industrial, manufacturing and exports sector relative to GDP.

The evidence in Table 2 is again mixed. Overall, there has been a steady but small increase in the mean industry and manufacturing ratio across the three periods. However, the annual average growth rate of manufacturing and exports declined in

${ }^{8}$ Intermediate goods accounted for 42 percent of the total 1990-91 value of production in our sample and the petroleum product group accounted for 23 percent of this value of production. The pesticides, insecticides, fungicides and herbicide group and the compressed liquified and solidified gas group together accounted for less than 1 percent of the value of production in the intermediate group category. For tables showing the disaggregate data. 
Table 2

Size and Annual Average Growth Rates of Industry, Manufacturing, and Export Ratios

\begin{tabular}{lccc}
\hline Period & SOI & SOM & SOE \\
\hline $1970-77$ & 21.38 & 14.39 & 11.69 \\
& $(0.59)$ & $(-0.41)$ & $(-6.04)$ \\
$1978-87$ & 23.06 & 16.66 & 11.26 \\
& $(0.40)$ & $(1.32)$ & $(2.79)$ \\
$1988-93$ & 25.39 & 17.38 & 12.14 \\
& $(1.19)$ & $(0.80)$ & $(2.74)$ \\
\hline
\end{tabular}

Source: World Bank World Tables 1994 data diskette.

Notes: Parentheses contains annual average growth rates for the period.

SOI = Size of industrial sector defined as real value-added in industry over real GDP.

$\mathrm{SOM}=$ Size of manufacturing sector defined as real value-added in manufacturing over real GDP.

SOE $=$ Size of exports defined a the real value of good and non-factor services over real GDP.

the liberalisation period compared to the earlier period. ${ }^{9}$ Also, the performance across the board is feeble compared to the performance of the new NICs. ${ }^{10}$

The export ratio increased over the three periods by less than 1 percent. However, there has been an improvement in growth rates from the negative 6 percent in the base period to close to positive 3 percent in the $1988-93$ period. ${ }^{11}$ The decline in export share in the second period and rise in the third structural adjustment period is broadly consistent with the finding in Table 2. The data reported below in Table 3 sets Pakistan's performance in a cross-country perspective.

The Table above shows that both in the base year, 1988, prior to structural adjustment, and in the terminal year, 1994, after several years of intensive structural adjustment, there is a substantial gap in Pakistan's industry ratio and those representing the mean for low income countries. The export ratio slipped from being slightly above the mean export for low income countries in 1988 to notably below it in 1994.

\footnotetext{
${ }^{9}$ The negative growth in manufacturing and exports in the base period coincides with the nationalisation of industry.

${ }^{10}$ SOI and SOM for Malaysia, Thailand and Indonesia in 1994 were 43, 39, and 41 percent and 32, 29 and 24 percent respectively. World Development Report 1996 (1996, pp. 210-211).

${ }^{11}$ The export ratio reached a low of -9.0 percent in 1977. Thus a positive growth rate of 2.79 percent in the second period was only able to barely make the mean in the second period equivalent to the mean in the base period.
} 
Table 3

Pakistan's Industry, Manufacturing, and Export Ratios

Compared to those of Low Income Countries

\begin{tabular}{lccccc}
\hline \multirow{2}{*}{ Year } & \multicolumn{2}{c}{1988} & & \multicolumn{2}{c}{1994} \\
\cline { 3 - 6 } Ratios & Pakistan & $\begin{array}{c}\text { Low Income } \\
\text { Countries }\end{array}$ & & Pakistan & $\begin{array}{c}\text { Low Income } \\
\text { Countries }\end{array}$ \\
\hline SOI & 24 & 36 & 25 & 34 \\
SOM & 17 & n.a. & 18 & 25 \\
SOE & 14 & 13 & 16 & 19 \\
\hline
\end{tabular}

Source: World Development Report 1996 (1996, p. 210, 212) and World Development Report 1990 (1990, p. 182, 194).

Another way of approaching this issue is to investigate how Pakistan is doing relative to its potential. One method of estimating potential is by using cross-country data and based on that infer how Pakistan could be expected to perform based on its population and per capita GDP. We conducted empirical exercises to examine Pakistan's industrialisation and export orientation in the context of cross country experience, again using $1970-77,1978-87$ and $1988-93$ as the three time periods.

The method used for these exercises is a straight forward one devised by Chenery and Syrquin (1975) to identify structural changes in economies. Among other variables, they estimated the size of the industrial sector as a function of per capita GNP and population and the squares of these variables. This was referred to as a "structural equation" and per capita GNP and population are viewed as proxies for both resource endowments and the size of the market. The estimating equation is as follows:

$$
\begin{aligned}
& S O I=\alpha+\beta_{1} P O P+\beta_{2} P O P+\beta_{3} P O P S Q+\beta_{4} P C G D P+ \\
& \beta_{5} P C G D P S Q+\beta_{6} D I+\mu \quad \ldots \quad \ldots \quad \ldots
\end{aligned}
$$

Where,

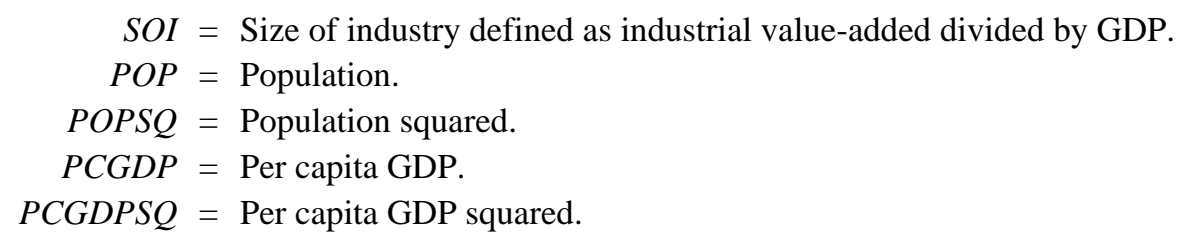

Once such an equation is estimated, it is possible to see how any country in the sample is performing relative to the cross-country experience by looking at the residual. For example, a positive residual for a country suggests its actual ratio (SOI or SOE) is certain number of percentage points above or below its potential ratio as suggested by cross country experience. 
We used two data sets. The first was the data tape of the World Bank World Tables 1994 from which we drew our left hand side variables, SOI and SOE. While per capita GDP was also available in the World Bank World Tables, this was not in purchasing power parity terms. Thus we used the Penn World Tables (Mark 5.6a) compiled under the supervision of Summers and Heston (1991) to extract PCGDP adjusted for purchasing power parity. ${ }^{12}$

The sample we used excluded countries which had a population of less than one million in the starting-period, the ex-socialist bloc countries, and countries that experienced a sustained high-intensity civil war in the relevant period. Countries for which there were some missing data also got excluded. This happened to include the high petroleum exporting countries. Data for manufacturing were not available for several countries and so we have done this exercise for only industry and exports. The results from estimating Equation 2 on this data set and sample are reported in Appendix Table I. ${ }^{13}$

Population is only a mildly significant positive predictor of the size of the industry in the 1988-93 period. In all periods, it has a negative and highly significant impact on the size of exports, suggesting that a larger population may result in more production for the non-traded sector and concomitant greater resource use in the non-traded sector. However, the magnitude of the impact is very small suggesting a .03 percent decline in the export ratio for a ten million increase in the population.

PCGDP and the square of this variable has the expected positive/negative sign as predictors of industrialisation in all periods. The Chenery and Syrquin stylised facts, verified here, suggest that industrialisation is expected to be positively associated with the increase in per capita GDP but, beyond some threshold, as the service sector expands, its relative importance in terms of its share in GDP is expected to decline. ${ }^{14}$

The main purpose of conducting this exercise was to explore if Pakistan's industrialisation and export-orientation was above or below potential and if this changed over time. Based on the regressions reported in Appendix Table I we computed the relevant residuals and the results are reported below in Table 4.

\footnotetext{
${ }^{12}$ Data were only available until 1992 for the PPP per capita GDP.

${ }^{13}$ The slight difference in the equations we estimated is the exclusion of the population square term for which we got a zero coefficient. The diagnostics of the straight OLS based on Chi-squared tests suggested a specification error and the related non-normality in the error term. These problems were resolved by logging the dependent variable. We corrected for hetroskedasticity where it was present. The sample of countries included for the estimation is reported in Khan (1997).

${ }^{14}$ It is implicitly assumed in the Chenery-Syrquin method that all countries follow the same industrialisation trajectory. We tested for this by using intercept and slope dummies for low and middle income countries and were able to reject separate trajectories.
} 
Table 4

The Extent to Which the Actual Size of Industry and Export GDP Ratio Differ from the Potential Based on Cross-country Experience (Percentages)

\begin{tabular}{lcc}
\hline Period & SOI & SOE \\
\hline $1970-77$ & -3.02 & -15.34 \\
$1978-87$ & -0.21 & -13.75 \\
$1988-93$ & -1.04 & -3.66 \\
\hline
\end{tabular}

Source: Based on cross-country regressions reported in Appendix III, Table I.

Notes: The percentages are calculated by dividing the residuals by the fitted values, where the fitted values are viewed as the potential.

The Table above shows that the actual industry ratio is below its potential in the three periods. The export ratio has been notably below potential in the first two periods but fell from 15.3 percent below potential in the first period (1970-77) to only 3.7 percent below in the intensive structural adjustment phase. Once again, this is consistent with earlier findings of increased export promotion in the structural adjustment period. Also, Pakistan falling further below its industrial potential in the structural adjustment period is consistent with earlier findings.

Of course, industrialisation and export orientation can not be viewed as ends in and of themselves. In fact both of them have been criticised in the progressive literature; industrialisation for negative environmental consequences; export orientation for this and for resulting in minority enriching and labour displacing enclave economies with few linkages with the domestic economy. Given these reservations, the endorsement of industrialisation (with safeguards) and export orientation need to based on demonstrating at least their positive contribution to GDP growth.

Following a method proposed by Bilginsoy and Khan (1994), we tested to identify if the industrial and export sector contribute externalities to the rest of the economy and if resources are more productively used in these sectors compared to the rest of the economy. On both counts we found no supporting evidence. ${ }^{15}$ However, we only had 23 years data (1970-93) and conclusive results would require many more observations. Thus for now one would have to rely on cross-country results to emphasise the importance of industrialisation in Pakistan.

${ }^{15}$ We have not reported the results here to conserve space. Details are reported in Khan (1997). 


\section{SUMMARY}

The major focus of this paper is on the impact of trade liberalisation on industrialisation and exports. While we have only been able to study part of the liberalisation period, so far the evidence concerning de-industrialisation and export promotion is mixed. We rely on several different kinds of evidence to reach this conclusion.

We found that export-orientation has become an increasingly important source of industrial growth in the consumer goods industry (about half of total industrial growth), particularly in the structural adjustment period. Correspondingly, import-substitution declined in importance and the trend suggests a displacement of imports. However, there is evidence of displacement of domestic production by imports in the intermediate goods sector.

The mean size of industry as a percentage of GDP at 25 percent in the structural adjustment period (1988-93) has increased by 4 percent compared to the base period (1970-77) while the size of the manufacturing sector increased by 3 percent (from 14 percent to 17 percent). Overall, mean exports as a percentage of GDP barely increased from 11.7 percent in the base period to 12.1 percent in the structural adjustment period. While the annual average growth rate of industry and manufacturing in the 1988-93 period was 0.6 percent and 1.2 percent above and below the base period respectively, that of exports was 8.8 percent greater than the base period. However, the annual average growth rate of both manufacturing and exports declined in the period of economic liberalisation compared to the earlier period.

While industrial and export growth has occurred, the evidence suggests that in neither case is Pakistan realising its potential or even matching the performance of low income countries. The growth of industry was 1.04 percent below its potential in the structural adjustment period compared to 0.2 percent below potential in the 1978-87 period. Also, compared to the category of low income countries in which Pakistan is included, Pakistan's industry and export ratios were substantially below the mean of low income countries in 1994.

There has been a steady improvement in export performance. Exports were 15.3 percent below potential in the base period but only 3.7 percent below potential in the structural adjustment period. The latter finding should not be cause for much celebration, since Pakistan's export ratio had also fallen behind the mean of low income countries in 1994 compared to being slightly ahead in 1988 .

To conclude, the performance of the consumer goods sector in promoting exports and displacing imports has been robust. Other evidence also points to an improvement in export performance, although Pakistan is still not meeting its export potential or matching the mean performance of even low income countries. Also, 
our findings cannot reassure those in Pakistan who feared that structural adjustment would usher in de-industrialisation. There is evidence of imports displacing domestic production in the intermediate goods sector and of average annual growth in industry declining and of industry growth falling further behind potential in the period of economic liberalisation compared to the earlier period.

Appendix

\section{Appendix I}

Industrial Growth Accounting

$$
\begin{aligned}
& \begin{array}{llllllll}
\Delta Q=\Delta Z & \ldots & \ldots & \ldots & \ldots & \ldots & \text { (i) }
\end{array} \\
& Z=\text { Total supply } \\
& Q=\text { Total demand } \\
& \begin{array}{lllll}
\Delta Z=\Delta X+\Delta M & \ldots & \ldots & \ldots & \ldots
\end{array} \\
& X=\text { Domestic production } \\
& M=\text { Imports }
\end{aligned}
$$

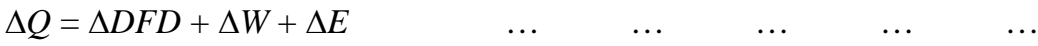

$$
\begin{aligned}
& D F D=\text { Domestic final demand } \\
& W=\text { Domestic intermediate demand } \\
& E \text { = Exports }
\end{aligned}
$$

Due to a lack of data, the two categories of domestic demand are merged into $D$ so that

$\Delta Q=\Delta D+\Delta E$

Starting with Equation 1, we can write

$$
\begin{aligned}
& X_{1} / Z_{1} * \Delta Q=X_{1} / Z_{1} * \Delta Z \\
& X_{1} / Z_{1} \Delta Q=X_{1} / Z_{1} * Z_{2}-X_{1} / Z_{1} * Z_{1} \\
& \mu_{1} \Delta Q=\mu_{1} Z_{2}+\left(X_{2}-X_{1}\right)-X_{2} \\
& \mu_{1} \Delta Q=\mu_{1} Z_{2}+\Delta X-X_{2} / Z_{2} * Z_{2} \\
& \mu_{1} \Delta Q=\mu_{1} Z_{2}+\Delta X-\mu_{2} Z_{2} \\
& \mu_{1} \Delta Q=\left(\mu_{2}-\mu_{1)} Z_{2}+\Delta X\right. \\
& \Delta X=\mu_{1} \Delta Q+\left(\mu_{2}-\mu_{1)} Z_{2}\right.
\end{aligned}
$$

Substituting for $\Delta Q$ from Equation (iv) we get

$$
\Delta X=\mu_{1} \Delta D+\mu_{1} \Delta E+\left(\mu_{2}-\mu_{1)} Z_{2} \quad \ldots \quad \ldots \quad \ldots \quad \ldots\right.
$$

Equation (v) is what has been estimated. If import substitution is constant, the change in total production that would result from a change in domestic demand is $\mu_{1}$ $(\Delta D+\Delta E)$. Where $\mu_{1}=X_{1} / \mathrm{Z}_{1}$ or domestic production to total supply in base year. 
Thus $\mu_{1} \Delta \mathrm{D}$ explains the change in domestic production that results from a change in domestic demand and the $\mu_{1} \Delta \mathrm{E}$ explains the change in domestic production that results from a change in export demand. Finally, there is a change in domestic production that can be ascribed to a change in import substitution holding demand constant which can be captured as $\left(\mu_{2}-\mu_{1}\right) Z_{2}$. Here $\mu_{2}=X_{2} / Z_{2}$ or domestic production to total supply in terminal year. If the ratio of domestic production to total supply increases in the terminal year compared to the base year, it can be attributed to domestic production displacing imports. The full decomposition expression then is as follows:

To repeat for emphasis, in Equation (v) the first two terms represents the change in domestic production resulting from a change in domestic demand and the change in exports holding import substitution constant, and the third term represents the change in domestic production resulting from a change in import substitution holding domestic demand constant.

\section{Appendix Table I}

Cross-country Regression to Identify Potential Size of Industry and Exports

\begin{tabular}{|c|c|c|c|c|c|c|}
\hline \multirow{2}{*}{$\begin{array}{l}\text { Time Period } \\
\text { Dependent } \\
\text { Variable }\end{array}$} & \multicolumn{2}{|c|}{ 1970-77 } & \multicolumn{2}{|c|}{ 1978-87 } & \multicolumn{2}{|c|}{ 1988-93 } \\
\hline & LSOI & LSOE & LSOI & LSOE & LSOI & LSOE \\
\hline Constant & $\begin{array}{c}2.76^{*} \\
(32.71)\end{array}$ & $\begin{array}{c}3.12^{*} \\
(22.57)\end{array}$ & $\begin{array}{c}2.82^{*} \\
(34.64)\end{array}$ & $\begin{array}{c}2.97^{*} \\
(23.23)\end{array}$ & $\begin{array}{l}-1.75^{*} \\
(22.22)\end{array}$ & $\begin{array}{c}2.85^{*} \\
(22.63)\end{array}$ \\
\hline $\begin{array}{l}\text { Per Capita } \\
\text { GDP }\end{array}$ & $\begin{array}{c}0.3 \mathrm{E}-3^{*} \\
(5.69)\end{array}$ & $\begin{array}{l}0.1 \mathrm{E}-4 \\
(0.89)\end{array}$ & $\begin{array}{c}0.2 \mathrm{E}-3^{*} \\
(6.23)\end{array}$ & $\begin{array}{l}0.8 \mathrm{E}-4 \\
(1.26)\end{array}$ & $\begin{array}{c}0.2 \mathrm{E}-3^{*} \\
(6.38)\end{array}$ & $\begin{array}{c}0.2 \mathrm{E}-3^{*} \\
(2.89)\end{array}$ \\
\hline $\begin{array}{l}\text { Per Capita } \\
\text { GDP }\end{array}$ & $\begin{array}{c}0.2 \mathrm{E}-7^{*} \\
(4.46)\end{array}$ & $\begin{array}{c}-0.2 \mathrm{E}-8 \\
(0.79)\end{array}$ & $\begin{array}{c}-0.1 \mathrm{E}-7^{*} \\
(5.40)\end{array}$ & $\begin{array}{c}-0.5 \mathrm{E} 8 \\
(1.02)\end{array}$ & $\begin{array}{c}-0.1 \mathrm{E}-7^{*} \\
(5.60)\end{array}$ & $\begin{array}{c}-0.8 \mathrm{E}-8^{* *} \\
(2.39)\end{array}$ \\
\hline $\begin{array}{l}\text { Squared } \\
\text { Population }\end{array}$ & $\begin{array}{l}0.6 \mathrm{E}-6 \\
(1.37)\end{array}$ & $\begin{array}{c}-0.3 \mathrm{E}-5^{*} \\
(3.69)\end{array}$ & $\begin{array}{c}0.5 \mathrm{E}-6^{*} \\
(1.64)\end{array}$ & $\begin{array}{c}-0.2 \mathrm{E}-5^{*} \\
(3.45)\end{array}$ & $\begin{array}{c}0.4 \mathrm{E}-6^{* * *} \\
(1.66)\end{array}$ & $\begin{array}{c}-0.2 \mathrm{E}-5^{*} \\
(2.89)\end{array}$ \\
\hline $\begin{array}{l}\text { R Bar Squared } \\
\mathrm{N} \\
\mathrm{F}\end{array}$ & $\begin{array}{c}.37 \\
78 \\
12.32^{*}\end{array}$ & $\begin{array}{c}.13 \\
80 \\
5.07^{*}\end{array}$ & $\begin{array}{c}.37 \\
81 \\
16.98^{*}\end{array}$ & $\begin{array}{c}.13 \\
81 \\
5.05^{*}\end{array}$ & $\begin{array}{c}.38 \\
79 \\
16.64^{*}\end{array}$ & $\begin{array}{c}.19 \\
80 \\
7.21^{*}\end{array}$ \\
\hline
\end{tabular}

Source: World Bank World Table 1994 for population, GDP value-added in industry, Exports of goods and non-factor services. Penn World Tables (5.6a) were used for per capita GDP in purchasing power parity (PPP) terms.

Notes: $\quad$ LSOI $=$ Size of the industrial sector defined as value-added in industry over GDP. The ratio was logged.

LSOE $=$ Size of exports defined as the value of goods and non-factor services exported over GDP. The ratio was logged.

Parentheses contain t-ratios.

* = Significant at least at the 1 percent level.

** = Significant at least at the 5 percent level.

$* * *=$ Significant at least at the 10 percent level. 


\section{REFERENCES}

Aftab, S. (1994) Scarcity Premia on Imports in Pakistan: An Update. SDPI. (Mimeograph.)

Agarwala, R. (1983) Price Distortions and Growth in Developing Countries. Washington, D. C.: World Bank. (World Bank Staff Working Papers No. 575.)

Balassa, B. (1985) Exports, Policy Choices, and Economic Growth in Developing Countries after the 1993 Oil Shock. Journal of Development Economics 18: 2335.

Chenery, H. B., and M. Sryquin (1975) Patterns of Development. London: Oxford University Press.

Chow, P. C. Y. (1987) Causality between Export Growth and Industrial Development. Journal of Development Economics 26: 55-63.

Dodaro, S. (1991) Comparative Advantage, Trade and Growth: Export-Led Growth Revisited. World Development 19: 1153-1165.

Dollar, D. (1992) Outward-Oriented Developing Economies Really do Grow More Rapidly: Evidence from 95 LDCs, 1976-1985. Economic Development and Cultural Change 40: 523-544.

Feder, G. (1982) On Exports and Economic Growth. Journal of Development Economics 12: 59-73.

Jung, W.S., and P. S. Marshall (1985) Exports, Growth and Causality in Developing Countries. Journal of Developing Economics 18: 1-12.

Kaldor, N. (1967) Strategic Factors in Economic Development. Ithaca: Cornell University Press.

Kavoussi, R. M. (1984) Export Expansion and Economic Growth: Further Empirical Evidence. Journal of Development Economics 14: 241-250.

Kemal, A. R. (1997) Patterns and Growth of Pakistan's Industrial Sector. In S. R. Khan (ed.) Fifty Years of Pakistan's Economy. Karachi: Oxford University Press. (Forthcoming.)

Khan, S. R. (1997) Trade Liberalisation, Industrialisation and Export Promotion. Sustainable Development Policy Institute, Islamabad. (Mimeograph.)

Khan, S. R., and C. Bilginsoy (1994) Industry Externalities Revisited. Kyklos 47: 67-80.

Khan, S. R., C. Bilginsoy, and M. S. Alam (1997) Dynamic Efficiencies of Industrialisation and Economic Growth: An Aggregative Analysis. Economia Internationale 50: (Forthcoming).

Levine, R., and D. Renelt (1992) A Sensitivity Analysis of Cross-country Growth Regressions. American Economic Review 82: 942-963.

Lewis, S. R. (1969) Economic Policy and Industrial Growth in Pakistan. London: George Allen and Unwin Ltd. 
Sheehey, E. (1992) Exports and Growth: Additional Evidence. Journal of Development Studies 28: 730-734.

Singer, H. W. (1989) Terms of Trade and Economic Development. In The New Palgrave: Economic Development. New York: W. W. Norton.

Summers, R., and A. Heston (1991) The Penn World Table (Mark 5): An Expanded Set of International Comparisons, 1950-1988. The Quarterly Journal of Economics 327-368.

Tyler, W. G. (1981) Growth and Export Expansion in Developing Countries. Journal of Development Economics 11: 121-130.

Weiss, J. (1988) Industry in Developing Countries: Theory, Policy and Evidence. New York: Routledge.

World Bank (1995) World Development Report 1995. New York: Oxford University Press. 